\title{
Ochrana spotřebitele jako projev změny společnosti aneb od civilních kodexu 19. století k moderním kodexům 21. století
}

\author{
Consumer Protection as Change in Society - From \\ the Civil Codes of the Nineteenth Century to the Modern Codes \\ of the Twenty-First Century
}

Markéta Selucká

\begin{abstract}
The author of the article focuses on a reflection upon the changing of society in civil codes, especially whether the codes adapted in the nineteenth century were based on the same values as those that are being drafted in the twenty-first century. The author also analyzes a new trend in private law that typically guarantees the protection of weaker parties in private law and, thus, interferes with the crucial principle of autonomy of will.
\end{abstract}

KEY WORDS Civil codes, changing of society and law, protection of weaker parties, autonomy of will

\section{Úvodem}

Stav společnosti či společenská realita, tj. fakticita našeho života či života naší společnosti, se odráží i v zákonodárství. Je-li společnost hodnotově „rozbředlác“ či neustálená, je-li základním motivem touha po zisku a majetku, bez ohledu na způsob získání majetkového prospěchu, odráží se tato skutečnost nejen v celkové demoralizaci (kdo řádně platí, je hlupák) a hodnotové zploštělosti celé společnosti, ale projevuje se to i v rámci zákonodárství. At' už jde o nechut' politické reprezentace přijímat „sebeomezující pravidla hry“, nebo jen o nechut' stanovení jasných pravidel chování. Nejasnost a nejistota právní úpravy otevírá možnosti ke zneužití práva jakožto normativního systému, který umožní těm bohatým a mocným uspokojit své fakticky neuspokojitelné touhy po majetku, zisku a luxusním blahobytu. Nicméně již Ovidius psal, že proto jsou zákony dány, aby silnější nemohl všechno (Ovidius, Fast. III, 279). Jsou zákony dány, aby silnější v naší společnosti nemohl všechno?

Proměny společnosti v běhu času se promítají nejen do literatury, hudby či obecně kultury, ale mají také podstatný vliv na zákonodárství toho kterého státu. Na společnost a její život mají vedle myšlenkových a hodnotových postulátů zásadní vlivy skutečnosti vznikající

Sociální studia. Katedra sociologie FSS MU, 2/2015. S. 119-133. ISSN 1214-813X. 
v rámci prostého vývoje lidské společnosti, a to zejména z lidské schopnosti myslet, rozvíjet se, vytvářet a objevovat nové, dosud nepoznané. Velký vliv na rozvoj a vývoj společnosti mají proto nové technické či vědecké poznatky, které zejména ve 21. století jsou objevovány s nesmírnou rychlostí. Je poměrně zajímavou otázkou, zdali humanitní vědy jsou schopny na překotný technický či př́mo kybernetický vývoj adekvátně reagovat a zdali např. zákonodárství je schopné zohlednit ve svých modelových řešeních překotnost vývoje lidské společnosti.

Obecně bychom mohli říci, že reálný stav společnosti (nejen politický, ale vzdělanostní, hodnotový atd.) se odráží i v zákonodárství. Zatímco kodexy soukromého práva vznikající za totalitního komunistického režimu byly charakteristické svým násilným přeskupením společnosti (neužívání pojmů „,fyzická osoba“, „právnická osoba“ a nahrazení pojmy „zaměstnanec“ či „spotř̌ebitel“) a brutální selekcí civilních institutů standardních pro běžné fungování společenských vztahů (užívací práva místo vlastnických, omezení obligačních institutů - např. neexistence práva nájmu atd. [Pelikánová a Pelikán 2014: XXXV]), kodexy 19. století bychom mohli charakterizovat jakožto kodexy „emancipačni“, tj. kodexy, které jsou standardní svým výslovným zakotvením uplatnění principů svobody, rovnosti a svrchovanosti. Kodexy 19. století tak obsahovaly nejen ochranu soukromých práv subjektů soukromého práva, ale i ochranu dnešních ústavních práv, tj. základních lidských práv, kterým se v současné době věnuje ústavní právo (Fiala 2012). Stěžejní otázkou, později ve vývoji částečně vyčleněnou do základních lidských práv, tak jsou otázky osobní svobody jednotlivce, které se projevují nejen v osobním statusu člověka, ale i v jeho svobodě obligační (zjednodušeně řečeno právo člověka uzavř́ít smlouvu s kým chci a za jakých podmínek chci), a zejména v ochraně vlastnického práva. Kodexy soukromého práva rovněž obsahovaly výslovné uznání rovnosti subjektů před zákonem. Zatímco v době před přijetím civilních kodexů se každá společenská skupina řídila svým právem (šlechta zemským, měštanstvo městským, duchovenstvo církevním právem), občanské zákoníky 19. století měly rozdíly odstranit a garantovat člověku - občanu rovnost, a to nejen rovnost z pohledu ústavněprávního, ale i z pohledu soukromoprávního. Svrchovanost bychom pak mohli charakterizovat jako právní uznání určité moci jednoho nad druhým, např. manžela nad manželkou, otce nad dítětem, zaměstnavatele nad zaměstnancem atd. (Horák 2013: XXXV).

Samozřejmě, že tyto zákonodárné počiny měly svůj primární původ v emancipaci prostého obyvatelstva, tj. zrušení poddanství, rušení lenních vztahů a celkového sebeuvědomění měšt’anského obyvatelstva. Revoluce přinášely změny do společenských vztahů a ty se mimo jiné více či méně odrážely i v porevolučním zákonodárství. Rovněž sametová revoluce v roce 1989 zásadním způsobem změnila společenské vztahy v naší společnosti. Totalitní ideologický systém byl nahrazen demokratickou společností, která má být charakteristická úctou k standardním zásadám demokratické společnosti, jako jsou svoboda, rovnost, slušnost, ale i odpovědnost a solidarita.

Společnost se od základu změnila, a proto bylo nutné na nové společenské vztahy reagovat i zákonodárstvím, tj. stanovit mantinely pro „budování kapitalismu“ a pro přechod z „garážového podnikání“ ke standardnímu způsobu podnikání v demokratické společnosti. Jedním z prvních zákonodárných počinů proto bylo přijetí zákona č. 116/1990 Sb., o nájmu a podnájmu nebytových prostor, který byl účinný již od 1. 5. 1990. Zákonodárce tak zavedl 
do právního řádu postkomunistické země standardní institut soukromého práva, který občanský zákoník v té době vůbec neznal (nájem). Teprve velkou novelou občanského zákoníku z roku 1964 (zák. č. 40/1964 Sb., občanský zákoník, dále „ObčZ 1964“) provedenou zákonem č. 509/1991 Sb. účinnou od 1. 1. 1992 došlo ke změně soukromého práva zásadním způsobem, nebot' do ObčZ 1964 byly zavedeny standardní občanskoprávní instituty demokratické společnosti, zpravidla známé od dob ř́mského práva.

Nicméně ve všech postkomunistických zemích se přes provedené novelizace socialistických civilních kodexů vedla, a v některých i nadále vede (např. Polsko či Slovensko), diskuse o nutnosti přijetí nového kodexu soukromého, či alespoň občanského práva. Zatímco Česká republika či Mad'arsko ${ }^{1}$ svůj nový civilní kodex přijaly, jiné země zatím usilovně pracují a pečlivě promýšlejí (zejména v Polsku) veškeré konsekvence modelových řešení do společenské reality.

Vzhledem k tomu, že postkomunistické země $\mathrm{v}$ Evropě jsou rovněž zpravidla členy Evropské unie (dále „EU“), mají nezanedbatelný vliv na modelová řešení obsažená v kodexech soukromého práva, modelová řešení obsažená v právu EU. Jaké jsou základní hodnoty prosazované novými civilními kodexy přijatými ve 21. století? V čem jsou soukromoprávní kodexy 21. století shodné s kodexy 19. století a jakým způsobem se odrazila změna společenské reality v civilním zákonodárství?

\section{Sociální funkce soukromého práva jako typický rys civilních kodexů 21. století}

Civilní kodexy 19. stol. byly charakteristické garancí principů svobody, rovnosti a svrchovanosti. Nový soukromoprávní kodex (zák. č. 89/2012 Sb., občanský zákoník účinný od 1. 1. 2014, dále „ObčZ“) v tomto směru ctí tradici civilních kodexů, když obsahuje v ustanovení § 3 odst. 1 ObčZ textaci: „Soukromé právo chrání důstojnost a svobodu člověka i jeho přirozené právo brát se o vlastní štěstí a štěstí jeho rodiny nebo lidí jemu blízkých takovým způsobem, jenž nepůsobí bezdůvodně újmu druhým.“ Můžeme proto poněkud lakonicky konstatovat, že současný civilní kodex stojí ideově na stejných základech jako kodex vzniknuvší před více než dvě stě lety, nebot' i OZO (ABGB'; Obecný zákoník občanský z roku 1811, dále „OZO“) obsahuje ustanovení § 16: „Každý člověk má vrozená, již rozumem poznatelná práva, a nutno jej tudíž považovati za osobu. Otroctví nebo nevolnictví a k tomu se vztahující výkon moci nejsou v těchto zemích dovolena.“

Jak OZO, tak i ObčZ stojí na tezi přirozených práv člověka, tj. považuje člověka za jedinečnou lidskou bytost $\mathrm{v}$ řádu bytí a $\mathrm{z}$ této skutečnosti dovozuje lidskou důstojnost a svobodu. Vedle toho však současný civilní kodex obsahuje možná poněkud „kontroverzní “ právo brát se o své štěstí, které vzbuzuje otázky stran právní, filosofické či právně-filosofické definice pojmu „štěsti'“, tj. jeho relativně neurčitého a filosoficky velmi diskutabilního obsahu, a proto celkově velmi ošidné aplikovatelnosti daného ustanovení (Selucká 2013: 2-3), přestože např.

„Polgári Törvénykönyv”; nový mad’arský občanský zákoník byl schválen 11. února 2013 a účinnosti nabyl dnem 15. března 2014.

2 Allgemeines bürgerliches Gesetzbuch. 
přirozené právo na štěstí obsahuje Deklarace nezávislosti Spojených států ze dne 4. července 1776 (Lavický 2014: 54). Obdobně necitlivě by asi působilo v českém právním prostředí opuštění Hedemannovy koncepce vlastnického práva ${ }^{3}$ a její nahrazení koncepcí „absolutni““. Vlastnictví má v rámci českého soukromého práva totiž významnou sociální funkci. Listina ${ }^{4}$ vlastnictví nevymezuje pouze individualisticky jako Deklarace práv člověka a občana ${ }^{5}$ či ústavy liberálního státu v 19. století, které vyzdvihovaly nedotknutelnost a zaručení vlastnictví, ale dává značný důraz na odpovědnost vlastníka vůči společnosti. To znamená, že vlastnické právo nemá sloužit pouze $\mathrm{k}$ uspokojování individuální potřeby vlastníka, ale má rovněž sloužit blahu společnosti. Obdobně bychom tak mohli říci, že člověku obecně svědčí právo na štěstí (aniž ovšem člověk je schopen identifikovat, co to štěstí je), avšak i toto štěstí nemůže být chápáno pouze individualisticky, ale musí být chápáno v kontextu blaha či štěstí celé společnosti.

V rámci prosazovaných hodnot $\mathrm{v}$ kodexech z 19. století je stěžejní otázka rovnosti před zákonem, tj. nerozlišování privilegovaných subjektů ve společnosti a zaručení toho, že se všemi bude zacházeno stejně, at’ už půjde o šlechtice, duchovního či „běžného občana“. Rovněž tak nemělo hrát roli, zdali je subjektem práva či povinnosti muž či žena, zletilý či nezletilý, občan daného státu či cizinec, katolík či protestant atd. V původních kodexech byla směšována základní lidská práva a práva soukromá. Zatímco současná právní věda striktně základní práva vyčleňuje a přiřazuje jim vyšší právní hodnotu právě s ohledem na povahu chráněného práva (ústavou chráněná práva), soukromá práva - včetně zajišsění rovnosti v soukromém právu - zůstávají nadále práva chráněná „pouze zákonem“. Z dnešního civilistického pohledu bychom mohli ř́ci, že civilní kodexy byly postaveny na modelu rovnosti formální a nezajímala ${ }^{6}$ je rovnost faktická ${ }^{7}$ (Bejček 2004, 2013), tj. zdali ve výsledku byl soukromoprávní vztah skutečně vyvážený a férový, nebo zdali jeden ze subjektů využil svého fakticky silnějš́ího postavení (napřs. majetný proti chudému). Naproti tomu pro kodexy 21. století je typické vyčlenění ústavních práv (základních lidských práv) do samostatného systému vyšší právní síly (Ústavy a Listiny) a zakotvení ochrany slabších subjektů v sou-

3 Evropský soudní dvůr (nyní Soudní dvůr Evropské unie) v případu č. 44/79 Liselotte Hauer v. Land Rheinland-Pfalz v bodě 20, uvádí, že sociální funkce vlastnictví je obvyklým standardem v evropských demokratických státech: ,[Z]ákonodárce může upravit užívání soukromého majetku v obecném zájmu. Některé ústavy přitom odkazují na imanentní vlastnické vazby (vlastnictví zavazuje) [...], další na sociální funkci vlastnictví [...], na to, že užívání vlastnictví má zároveň sloužit obecnému prospěchu [...], a na požadavky sociální spravedlnosti [...]. Ve všech členských státech má sociální funkce vlastnického práva konkrétní legislativní výraz. Všude také jsou stanovena omezení vlastnického práva v oblasti zemědělství a lesnictví, vodohospodářství, ochrany životního prostředí, územního plánování a urbanismu.“

4 Čl. 11 odst. 3 Listiny základních práv a svobod: „Vlastnictví zavazuje. Nesmí být zneužito na újmu práv druhých anebo v rozporu se zákonem chráněnými obecnými zájmy. Jeho výkon nesmí poškozovat lidské zdraví, prrírodu a životní prostředí nad míru stanovenou zákonem.“

5 La Déclaration des droits de l'homme et du citoyen ze dne 26. srpna 1789.

6 Samozřjmě, že i kodexy 19. století znaly institut dobrých mravů či dobré víry, která byla chráněna a ctěna, nicméně nebyla chápána tak široce, jako je tomu nyní.

7 Nikoli ovšem nahrazení formální rovnosti rovnostářstvím. 
kromém právu, tj. chráněná hodnota rovnosti se „zkvalitnila“, a zatímco rovnost formální je spíše chápána $\mathrm{v}$ demokratickém státě jako samozřejmost, chráněná hodnota rovnosti se posouvá do rovnosti faktické, tj. má býti zaručeno nejen to, že subjekt si je roven s jiným subjektem před zákonem, ale i to, že slabší subjekt bude chráněn před subjektem silnějším a bude tak „uměle“ vyrovnána faktická nerovnost subjektů daného právního vztahu.

ObčZ v ustanovení § 3 odst. 2 písm. c) výslovně uvádí, že „nikdo nesmí pro nedostatek věku, rozumu nebo pro závislost svého postavení utrpět nedůvodnou újmu; nikdo však také nesmí bezdůvodně těžit z vlastní neschopnosti k újmě druhých". Z $Z$ hlediska soukromého práva tak nejde již o to, že nikdo nesmí být otrokem či nevolníkem jiného člověka (tato hodnota je chráněna ústavou), ale nikomu nesmí být na újmu „závislost na druhém“. Závislý (slabší strana) tak musí být chráněn takovým způsobem, aby $\mathrm{k}$ utrpění nedůvodné újmy nedošlo.

Přes počáteční rezervovaný postoj zpracovatelů ObčZ k evropským principům a zásadám prosazujícím ochranu slabších, a to zejména spotřebitele (Selucká 2009) ${ }^{8}$, musíme konstatovat, že ObčZ se nechal inspirovat evropskými trendy k ochraně slabších v soukromém právu, at’ už tyto trendy „,byly vnuceny“ českému zákonodárci nutností harmonizace soukromého práva s právem EU (zejména směrnice na ochranu spotřebitele či soutěžitele), nebo vyplývají z obecné diskuse právních teoretiků nad evropským soukromým právem (von Bar 2009), např. DCFR ${ }^{9}$, Acquis pravidla ${ }^{10}$, PECL $^{11}$, PETL $^{12}$, či byly inspirovány např. velkou novelou $\mathrm{BGB}^{13}$. V některých členských státech $\mathrm{EU}$ jsou totiž směrnice na ochranu spotřebitele transponovány výlučně jako speciální ustanovení chránící spotřebitele, jiné členské státy implementují směrnice na ochranu spotřebitele i do obecných částí závazkového práva, takže se modelová řešení primárně určená pro ochranu spotřebitele stávají obecnými modelovými řešeními závazkového práva. Rozsáhlá novela $\mathrm{BGB}^{14}$ účinná od 1. ledna 2002 a označovaná v Německu jako „modernizace závazkového práva“ (Schuldrechtsmodernisierung [Krajewski 2003]) vnesla do tohoto civilního kodexu nejen např. základní principy předsmluvní odpovědnosti, ale do obecné části závazkového práva zavedla jako obecné instituty,

8 Nový civilní kodex měl být prost ustanovení na ochranu spotřebitele, ovšem vzhledem k tomu, že ČR je členským státem EU, nebylo možné směrnice na ochranu spotřebitele ignorovat. Nabízelo se dvojí řešení, zapracovat do ObčZ směrnice na ochranu spotřebitele, což původně zpracovatelé návrhu ObčZ striktně odmítali pro relativní „,nestabilnost“ práva EU, nebo vedle toho paralelně připravovat zákon na ochranu spotřebitele, který by obsahoval nikoli veřejnoprávní ochranu, tj. ochranu prosazovanou státem (jako je tomu převážně v zákoně o ochraně spotřebitele, zák. 634/1992 Sb.), ale ochranu soukromoprávní. V rámci př́ípravy rekodifikace soukromého práva však žádné paralelní práce na spotřebitelském kodexu neprobíhaly, což bylo oprávněně kritizováno českými civilisty.

9 Draft Common Frame of Reference (Návrh společného referenčního rámce).

10 Acquis principles. Blíže např. http://www.acquis-group.jura.uni-osnabrueck.de.

11 Principles of European Contract Law (Pravidla [principy] evropského smluvního [závazkového] práva).

12 Principles of European Tort Law (Pravidla [principy] evropského deliktního práva).

13 Bürgerliches Gesetzbuch (německý občanský zákoník).

14 Aktuální verze BGB je dostupná na stránkách Spolkového ministerstva spravedlnosti. Dostupné z: http://bundesrecht.juris.de/bgb/ [cit. 12. července 2014]. 
zásady a ideje, které pronikly a začaly se prosazovat díky transpozici či implementaci směrnic na ochranu spotřebitele.

Nový civilní kodex tak obsahuje obecnou zásadu ochrany slabších bez rozlišení povahy subjektu (Melzer a Tégl 2013: 84-85), tj. není rozhodné, zdali slabším subjektem bude spotřebitel, nájemce bytu, poškozený, drobný podnikatel, soutěžitel, příp. subjekt nemající pojmové znaky ani jednoho z uvedených specifických subjektů soukromého práva. Můžeme tedy konstatovat, že zatímco na počátku 21. století jsme si kladli otázku, zdali ochrana slabší strany může být zásadou soukromého práva (Selucká 2004), nový soukromoprávní kodex ji výslovně v katalogu svých zásad již obsahuje. Hodnotový posun je tedy flagrantní.

\section{Ochrana slabší strany a instituty ji zajišłující}

Vedle toho, že nový civilní kodex obsahuje výslovně ve svém katalogu zásadu ochrany slabších subjekti̊ v soukromém právu, není ustanovení $\S 3$ odst. 2 písm. c) ObčZ pouhou proklamací, nebot' v rámci další úpravy nabízí ObčZ specifické instituty, které tuto ochranu slabších subjektů mají zajišstovat. Dle našeho názoru je nutné ochranu slabších stran klasifikovat podle toho, zdali jde o obecnou ochranu slabšího subjektu v soukromém právu (srov. např. $\S 433$ ObčZ $^{15}$ ), nebo zdali se poskytuje specifická ochrana subjektu majícímu zvláštní atributy (napřr. spotřebitel, nájemce bytu, soutěžitel).

Mezi obecné instituty zajišt’ující ochranu slabších stran můžeme zařadit adhezní smlouvy (§ 1798-1801 ObčZ), tj. zjednodušeně řečeno smlouvy uzavírané pomocí formuláře, který obsahuje již práva a povinnosti kontrahentů, takže slabší strana bud' může vyslovit s formulářem souhlas, nebo k uzavření kontraktu zpravidla vůbec nedojde. Dále pak laesio enormis (neúměrné zkrácení či zkrácení přes polovic ${ }^{16}$ ), nemožnost sjednání kratší nebo delší promlčecí lhůty v neprospěch slabší strany (§ 630 odst. 2 ObčZ), ale i zavedení pojmu „zákazník“ do práva nekalé soutěže (srov. § 2976 odst. 1 ObčZ), tj. není rozhodné, kdo byl nekalosoutěžním jednáním postihnut, zda to byl jiný soutěžitel či spotřebitel (člověk nepodnikající), může to být i jiný podnikatel, který není soutěžitelem, př́íp. i jiný subjekt nesubsumovatelný pod žádný zmíněný právní pojem.

Dle našeho názoru můžeme mezi instituty prosazující ochranu slabší strany zařadit i clausula rebus sic stantibus (změna okolností17), i když by se tak na první pohled nemusel

„(1) Kdo jako podnikatel vystupuje vůči dalším osobám v hospodářském styku, nesmí svou kvalitu odborníka ani své hospodářské postavení zneužít k vytváření nebo k využití závislosti slabší strany a k dosažení zř̉ejmé a nedůvodné nerovnováhy ve vzájemných právech a povinnostech stran. (2) Má se za to, že slabší stranou je vždy osoba, která vůči podnikateli v hospodářském styku vystupuje mimo souvislost s vlastním podnikáním.“

$16 § 1793$ odst. 1 ObčZ: „Zaváží-li se strany k vzájemnému plnění a je-li plnění jedné ze stran v hrubém nepoměru k tomu, co poskytla druhá strana, může zkrácená strana požadovat zrušení smlouvy a navrácení všeho do původního stavu, ledaže jí druhá strana doplní, oč byla zkrácena, se zřetelem k ceně obvyklé v době a místě uzavření smlouvy. To neplatí, pokud se nepoměr vzájemných plnění zakládá na skutečnosti, o které druhá strana nevěděla ani vědět nemusela.“

$17 \S 1765$ odst. 1 ObčZ zní: „Dojde-li ke změně okolností tak podstatné, že změna založí v právech a povinnostech stran zvlášt hrubý nepoměr znevýhodněním jedné z nich bud' neúměrným zvýšením 
jevit (srov. Eliáš 2009). Stricto sensu sice chrání stranu až poté, co došlo ke změně okolností, které zapř́činily zvlášt' hrubý nepoměr $\mathrm{v}$ právech a povinnostech stran, avšak právě onou změnou okolností se mění do té doby závazek dvou rovných subjektư ${ }^{18} \mathrm{v}$ nerovný vztah, a proto je nutné chránit slabší stranu vznikem práva na nové jednání o smlouvě či právem na zrušení smlouvy. Náš právní řád dokonce připouští ingerenci soudu do sjednané smlouvy takovým způsobem, aby navrátil právní vztah do vyváženosti.

Institut clausula rebus sic stantibus není obecně přijímán v rámci Evropy bez výhrad. Zatímco německá právní doktrína vypracovala pojetí tohoto institutu „až $\mathrm{k}$ dokonalosti““ a učinila z něj zásadní institut německého soukromého práva, jiné členské státy $\mathrm{EU}$, napřr. Francie ${ }^{19}, \mathrm{k}$ němu přistupují se značnou rezervou, nebot' striktně trvají na zásadě pacta sunt servanda $\mathrm{s}$ tím, že rozumný podnikatel musí nést riziko svého podnikání (v př́padě vztahů B2 ${ }^{20}$ se pak aplikace institutu clausula rebus sic stantibus zpravidla připouští) a nemůže svým neodpovědným jednáním ohrožovat jiné. Nicméně i francouzské právo je tímto institutem ovlivněno a postupně se právní úprava mění ve prospěch prolomení důsledného prosazování zásady pacta sunt servanda (srov. Girsberger a Zapolskis 2012; Brunner 2009).

\section{Ochrana specifické slabší strany - ochrana spotřebitele}

Především je nutné odlišit pojem „spotřebitel“ jakožto pojem právní a pojem „spotřebitel“ jakožto pojem sociologický (blíže Ondřej 2013). Mezi tyto dva pojmy není možné položit rovnítko. Právní pojem „spotřebitel“ je dále nutné chápat ve světle generální definice (srov. $\S 419$ ObčZ) a ve světle dalších speciálních definic, které nám český právní řád poskytuje, př́p. i v kontextu jakých chráněných právních vztahů spotřebitel vystupuje (viz dále).

Na začátku minulého století se ochrana člověka jako spotřebitele jevila jako utopie či politicky nekorektní názor, což lze demonstrovat např. na citátu z Ottova slovníku naučného:

Spotřebitelská politika je pojem, vzniklý po svět. válce a označující záměrnou péči, zejména státu a jiných veřejných korporací, o vytvoření a zachování příznivých podmínek na domácím trhu s hlediska spotřeby. Spotřebitelská politika má tedy uplatňovati spotřebitelská hlediska v praktickém hospodářském životě a prrípadně i usilovati o vyrovnání zájmů výrobních se zájmy spotřebitelskými. Souvisí to $\mathrm{s}$ jistým názorem na spotřebu vůbec, pokud se pak vlastní spotřebitelské politiky týče, tu stoupenci její usilují, aby se ve veřejném životě dostalo právům a zájmům spotřebitelů stejného formálního zastoupení, jaké mají kruhy výrobní. Zapomíná se

nákladů plnění, anebo neúměrným snížením hodnoty předmětu plnění, má dotčená strana právo domáhat se vi̊či druhé straně obnovení jednání o smlouvě, prokáže-li, že změnu nemohla rozumně předpokládat ani ovlivnit a že skutečnost nastala až po uzavření smlouvy, anebo se dotčené straně stala až po uzavření smlouvy známou. Uplatnění tohoto práva neopravňuje dotčenou stranu, aby odložila plnění.“

18 Pravděpodobně jde svým způsobem o presumpci vyváženosti původního právního vztahu.

19 Např. Francie, která striktně trvá na zásadě, že smlouvy se mají dodržovat (srov. § 1134 Francouzského Code Civil). Dále pak např. př́ípad Canal de Craponne (31. prosince 1873 rozsudek soudu Aix; Kasační soud, Civ., 6. 3. 1876). Výjimka je připuštěna pouze v př́ipadě veřejného zájmu (např. se týká velkého počtu obyvatel), srov. případ Gaz de Bordeaux (NSS Fr, 30. 3. 1916).

20 Business to consumer (spotřebitelský vztah), tj. vztah mezi podnikatelem a spotřebitelem. 
při tom namnoze, že spotřebitel je jenom hospodářský pojem, vyznačující určitý úsek celkové hospodářské činnosti, že to není žádný stav, který by se mohl s úspěchem uplatnovati politicky ve veřejném životě. Každý člověk je spotřebitelem, ale současně je zpravidla nějak zúčastněn i na výrobním procesu. Absolutních spotřebitelů vlastně není (snad jen pensisti, ale i ti odvozují své důchodové nároky od své činnosti předcházející). Proto volání po vytvoření spotřebitelských korporací samosprávných, odpovídajících obdobným korporacím podnikatelským, je pochybené. Jsou to pojmy nesourodé. Přes to však Spotřebitelská politika měla značný ohlas i v tomto směru, takže i u nás se usilovalo o zřízení „spotřebního ministerstva“" a organizací spotřebitelských. Krs. (Ottova encyklopedie 2003)

Vývoj společnosti však šel právě tímto politicky nekorektním způsobem, tj. nejen že spotřebitel se stal „hybatelem blahobytu současné společnosti“, ale stal se z něj pojem právní, který vyjadřuje záměr a cíl společnosti chránit člověka neprofesionála a konzumenta před rafinovaností profesionálů, kteří jsou v zásadě na spotřebě existenčně závislí, a proto se snaží člověka přimět všemi možnými i nemožnými zpơsoby k tomu, aby spotřebovával, aby kupoval. Pozitivní zakotvení ochrany spotřebitele v jednotlivých právních řádech tak, jak ji chápeme dnes, nalézáme v právních úpravách států od 60. let minulého století (Cartwright 1999).

Ochranu spotřebitele tak musíme chápat jako ochranu specifických slabších stran, které si zasluhují zvláštní ochrany vedle ochrany poskytované obecnými ustanoveními o ochraně slabších. Poměrně novým trendem ObčZ je, že prosazuje obecnou ochranu slabších subjektio, nikoli pouze spotřebitelů, a vedle toho ještě zajišt'uje ochranu i specifickým subjektům, mimo jiné i spotřebitelům. ObčZ definuje spotřebitele v ust. § 419: „Spotřebitelem je každý člověk, který mimo rámec své podnikatelské činnosti nebo mimo rámec samostatného výkonu svého povolání uzavírá smlouvu s podnikatelem nebo s ním jinak jedná. “Za spotrrebitele tak musí být považován pouze člověk, který nekoná v rámci svého podnikání, kdy není rozhodné, jakého právního vztahu se účastní, tj. nemělo by být rozhodné, zdali realizuje absolutní majetkové právo (např. zdali užívá předmět svého vlastnictví), nebo relativní majetkové právo (např. zdali uzavírá nájemní smlouvu, na základě které pak užívá předmět, který vlastní někdo jiný).

Rovněž právo EU chápe spotřebitele výlučně jako člověka - fyzickou osobu (zejména ve smyslu směrnice 93/13/ES; viz prŕípad ESD/SDEU, C-541 a 542/99, ve věci Cape and Idealservice MN RE). Avšak jednotlivé členské státy EU prristupují k pojmu „spotřebitel“ diferencovaně (Schulte-Nölke, Twigg-Flesner a Ebers 2007). Některé státy definují ve svém právu spotřebitele stejně jako ČR, tj. jakožto fyzickou osobu (např. polský občanský zákoník byl novelizován a spotřebitel je v právní úpravě de lege lata výlučně fyzická osoba, ačkoli předcházející pojetí vymezovalo spotřebitele také jako právnickou osobu). Jiné právní rády (např. Španělsko, Belgie, Dánsko, Francie) tolerují, aby za spotřebitele byla považována i osoba právnická, další dokonce umožňují, aby byl pojem „spotřebitel““ vykládán tak, že jím může být podnikatel, který činí výjimečné právní jednání (Francie, Lucembursko, Litva, Velká Británie).

Evropské právo však zná i výjimky z obecného pojetí spotřebitele jako fyzické osoby, např. je tato výjimka definována ve směrnici 90/314/EHS ${ }^{21}$, která umožňuje, aby spotřebitelem byla i osoba právnická, a to i osoba, která činí právní jednání v rámci své podnikatelské

21 Směrnice Rady 90/314/EHS ze dne 13. června 1990 o souborných službách pro cesty, pobyty a zájezdy. 
činnosti. Tento názor zastává i německá judikatura (Bundesgerichtshof, 16. 4. 2002, sp. zn. X ZR 17/01), která se již zabývala otázkou, zdali může být spotřebitelem ve smyslu směrnice 90/314/EHS rovněž právnická osoba - podnikatel, a príijala závěr, že tento výklad je souladný se směrnicí 90/314/EHS (společnost, která svým zákazníkům v rámci reklamní akce poskytla zájezd na fotbalové utkání mezi Německem a USA, byla chápána jako spotřebitel ve smyslu směrnice 90/314/EHS v závazkovém vztahu s cestovní kanceláŕí poskytující tuto službu).

Avšak právní úprava obsahuje rovněž specifickou ochranu spotřebitele podle toho, jakým způsobem dochází k uzavření smlouvy, tj. je zohledňována skutečnost, zdali spotřebitel má čas a nezávislost k prozkoumání podmínek smlouvy ${ }^{22}$ (blíže např. film Šmejdi), či zdali si např. nemůže prohlédnout předmět plnění23 (typicky internetové e-shopy).

Vedle této obecné ochrany spotřebitele pak nacházíme partikulární ochranu spotřebitele podle předmětu plnění, takže spotřebitel je chráněn zvláštním způsobem jako kupující, objednatel díla, dlužník (úvěrovaný), jde-li o spotřebitelský úvěr, pojistník v príípadě uzavření pojistné smlouvy atd. Obdobné můžeme říci i o ochraně nájemce bytu, nebot' vzhledem $\mathrm{k}$ tomu, že nájemce bytu bude zpravidla mít rovněž atributy spotřebitele a pronajímatel pak bude zpravidla charakterizován jako podnikatel, tj. půjde o klasický spotřebitelský vztah (B2C), můžeme i právní úpravu na ochranu nájemce bytu či nájemce (rodinného) domu chápat jako specifickou ochranu spotřebitele podle předmětu plnění (Selucká 2008).

Někteří právní vědci považují ochranu spotřebitele v soukromém právu za „,přehnanou“ a domnívají se, že narušení stěžejní zásady pacta sunt servanda a zásady autonomie vůle ohrožuje samotnou podstatu soukromého práva založenou na svobodě jednotlivcově. Je ochrana spotřebitele skutečně přehnaná? Nereagují instituty prosazující ochranu spotřebitele vlastně jen na společenskou poptávku, tj. na nutnost chránit dezorientovaného a hodnotově vykořeněného člověka před silnějšími rafinovanými profesionály, ale vlastně i před ním samým?

\section{Informovaný spotřebitel - základní kámen jeho ochrany}

Právo EU považuje za stěžejní institut prosazující a garantující účinnou ochranu slabší strany - spotřebitele - zavedení informační povinnosti silnější strany vůči straně slabší. Lidově řečeno, spotřebitel by měl vědět, „do čeho jde“, tj. jaké bude mít povinnosti a práva. Nový občanský zákoník vychází z presumpce člověka, který má „zdravý selský rozum“. (§ 4 odst. 1 ObčZ: „Má se za to, že každá svéprávná osoba má rozum průměrného člověka i schopnost užívat jej s běžnou péčí a opatrností a že to každý od ní může v právním styku důvodně očekávat.") Proto by vlastně ani neférovou smlouvu neměl uzavřít. Praxe nás však poučuje o pravém opaku. Vědomostní složka právního jednání, ovlivňující rozhodování spotřebitele, bude $\mathrm{v}$ tomto př́padě zásadní. Informační povinnost tak musí být vůči spotřebiteli realizována tak, aby informace poskytované spotřebiteli měly určitou kvalitu, tj. aby byly jasné a srozumitelné, a to jasné a srozumitelné osobě se zdravým rozumem, resp. osobě s rozumem průměrného člověka. Pokud jsou informace poskytovány „sofistikovanou

22 Smlouvy uzavírané mimo obchodní prostory (§ 1820 a násl. ObčZ).

23 Smlouvy uzavírané distančním způsobem (§ 1820 a násl. ObčZ). 
formou“, tj. tak, aby spotřebitel nevěděl, do čeho jde, pak silnější strana nesplnila svou informační povinnost a ustanovení smlouvy takto definovaná by neměla spotřebitele zavazovat. Německý soud v př́ípadu sp. zn. X ZR 253/0124 uvedl, že

smluvní ustanovení obsahující jednostranné navýšení ceny zájezdu v důsledku navýšení nákladů spojených se zájezdem není možné bez stanovení přesného způsobu výpočtu. Takové ustanovení musí být určité a srozumitelné. Jednostranné navýšení ceny zájezdu je možné jen př̆i splnění podmínek uvedených v čl. 4 odst. 4 směrnice 314/90/EHS, kde je mj. vyjádřen i princip transparentnosti, který zajišt’uje ochranu smluvního partnera poskytovatele zájezdu. ${ }^{25}$

V obdobném duchu rozhodoval napr. i Rakouský soud (Oberster Gerichtshof, 11. 7. 2005, sp. zn. 7 Ob 117/05i), když dovodil, že spotřebitel musí být schopen si zvýšení ceny zájezdu sám spočítat, a pokud je vzorec spotřebiteli „nesrozumitelný“, pak právo na zvýšení ceny zájezdu cestovní kanceláři nesvědčí.

Informační povinnost musí být proto realizována takovým způsobem, aby objektivně spotřebitel se zdravým rozumem (průměrného rozumu) byl schopen z poskytnutých informací pochopit, jaká práva a povinnosti mu budou v daném právním vztahu svědčit. Samotná informační povinnost je rozdělena do tří částí vážících se na určité okamžiky fáze vztahu mezi spotřebitelem a podnikatelem (předsmluvní informační povinnost, informační povinnost $\mathrm{v}$ okamžiku uzavření smlouvy a informační povinnost $\mathrm{v}$ průběhu existence právního vztahu mezi podnikatelem a spotřebitelem).

Na druhou stranu $\mathrm{v}$ době informační společnosti zdá se být postavení ochrany spotřebitele na modelu informovaného spotřebitele svým způsobem poněkud iluzorní, nebot' v okamžiku, kdy smlouva či obchodní podmínky obsahují, dř́ve zpravidla velmi drobným, sotva čitelným písmem, několik stran, spotřebitel fakticky rezignuje na seznámení se s nimi a „tupě“ odklikne či podepíše, že se s nimi seznámil a že s nimi souhlasí, aniž by tak učinil. Informační povinnost tak nesplnila svou zásadní funkci, aby právní jednání činil spotřebitel, který ví, do čeho jde. Ochrana spotřebitele tak zjevně selhala.

Ústavní soud v nálezu ze dne 11. listopadu 2013, sp. zn. I. ÚS 3512/2011 reagoval na tuto skutečnost poměrně zásadním způsobem. Poskytovatel internetu společnost UPC, a.s., měla $\mathrm{v}$ rámci obchodních podmínek ustanovení o smluvní pokutě za to, když při ukončení závazku prŕijemce služby nevrátí modem poskytovateli řádně a včas. Ustanovení o smluvní pokutě v obchodních podmínkách charakterizoval Ústavní soud jako překvapivé ujednání, které nemůže spotřebitel v obchodních podmínkách očekávat. Ústavní soud výslovně uvedl:

Je třeba zdůraznit, že obchodní podmínky ve spotřebitelských smlouvách na rozdíl třeba od obchodních smluv mají sloužit především $\mathrm{k}$ tomu, aby nebylo nezbytné do každé smlouvy přepisovat ujednání technického a vysvětlujícího charakteru. Naopak nesmějí sloužit k tomu, aby do nich v často nepřehledné, složitě formulované a malým písmem psané formě skryl dodavatel ujednání, která jsou pro spotřebitele nevýhodná a o kterých předpokládá, že pozornosti spotřebitele nejspíše uniknou (například rozhodčí doložka nebo ujednání o smluvní pokutě). Pokud tak i přesto dodavatel učiní, nepočíná si v právním vztahu poctivě a takovému jednání nelze přiznat

24 Německo, Bundesgerichtshof, ze dne 19. 11. 2002, sp. zn. X ZR 253/01.

25 Volný překlad. Blíže viz http://www.eu-consumer-law.org (cit. 1.-25. července 2014). 
právní ochranu ${ }^{26}$. [...] V rámci spotřebitelských smluv ujednání zakládající smluvní pokutu zásadně nemohou být součástí tzv. všeobecných obchodních podmínek, nýbrž toliko spotřebitelské smlouvy samotné (listiny, na niž spotřebitel připojuje svůj podpis).

Zákonodárce nicméně ${ }^{27}$ nabídl v rámci ObčZ jiné modelové řešení, které poskytne ochranu slabší straně (tedy i spotřebiteli) také v tomto př́padě, a to za předpokladu, že překvapivé ujednání v obchodních podmínkách je pro slabší stranu (tedy nejen spotřebitele) zvlášt' nevýhodné. Pak bude právní jednání (tato část obchodních podmínek) neplatné, a budou-li to vyžadovat okolnosti daného př́padu, může soud dokonce ingerovat do smluvního ujednání takovým zpơsobem, aby nastalá nerovnost či nespravedlnost byla odstraněna a bylo opět dosaženo rovného a vyváženého právního vztahu mezi subjekty soukromého práva, tj. soud autoritativně určí smluvním stranám, jaká práva a povinnosti jim svědčí. Jde tedy o poměrně zásadní zásah do autonomie vůle, tj. do volby, za jakých podmínek subjekt soukromého práva smlouvu uzavře.

Vedle obecné ideje informovaného spotřebitele v soukromém právu obsahují ustanovení ObčZ prosazující ochranu spotřebitele i jiné instituty, které zajišt'ují dostatečnou ochranu slabší kontraktační straně - spotřebiteli. Mezi obecné a zásadní instituty můžeme řadit výkladové pravidlo ,vždy ve prospěch spotřebitele“28 či zákaz odchylky od zákonných ustanovení na ochranu spotřebitele ${ }^{29}$. ObčZ rovněž obsahuje „,black list“ ujednání, která jsou jednoduše ve spotřebitelských smlouvách zakázána ( $\$ 1814$ ObčZ), a pokud by je spotřebitelská smlouva či s ní spojené obchodní podmínky obsahovaly, pak se jimi právní vztah neříí (nepřihlíží se k nim, tj. jde o neexistující či nicotná ujednání spotřebitelské smlouvy). Pokud by ustanovení spotřebitelské smlouvy mohlo být charakterizováno jako zakládající významnou nerovnováhu práv a povinností stran v neprospěch spotřebitele (tzv. nepřiměřené ujednání), pak ani taková část spotřebitelské smlouvy nebude spotřebitele zavazovat, přestože by nebyla subsumovatelná pod skutkové podstaty definované v „,black listu“.

Obecně tedy je nutné trvat na tom, že došlo k hodnotovému posunu civilních kodexů v 21. století, tj. chráněné hodnoty se mnohdy změnily, upřesnily či vykrystalizovaly do podoby, kterou možná tvůrci kodexů 19. století nemohli ani tušit. Máme však za to, že změna či upřesnění chráněných hodnot v kodexech soukromého práva ve 21 . století souvisí s celkovým vývojem demokratické společnosti.

26 Srov. § 6 ObčZ, který zní: „(1) Každý má povinnost jednat v právním styku poctivě. (2) Nikdo nesmí těžit ze svého nepoctivého nebo protiprávního činu. Nikdo nesmí těžit ani z protiprávního stavu, který vyvolal nebo nad kterým má kontrolu.“

27 Srov. § 1800 odst. 2 ObčZ: „Obsahuje-li smlouva uzavřená adhezním způsobem doložku, která je pro slabší stranu zvláště nevýhodná, aniž je pro to rozumný důvod, zejména odchyluje-li se smlouva závažně a bez zvláštního důvodu od obvyklých podmínek ujednávaných v obdobných případech, je doložka neplatná. Vyžaduje-li to spravedlivé uspořádání práv a povinností stran, soud rozhodne obdobně podle $\S 577$.“

28 Ust. § 1812 odst. 1 ObčZ: „Lze-li obsah smlouvy vyložit různým způsobem, použije se výklad pro spotřebitele nejpříznivější.“

29 Ust. § 1812 odst. 2 ObčZ: „K ujednáním odchylujícím se od ustanovení zákona stanovených k ochraně spotřebitele se neprrihlíží. To platí i v případě, že se spotřebitel vzdá zvláštního práva, které mu zákon poskytuje.“ 


\section{Závěrem}

Člověk se v 19. století emancipoval na občana, aby se posléze ve 21. století stal spotřebitelem, tj. člověk se emancipoval z otroctví člověku, aby se stal otrokem spotřeby, otrokem mocných nadnárodních korporací, otrokem svého vlastního chtění. Nákupní marketingový slogan Drogerie dm je př́mo na ztotožnění lidství a nakupování postaven: „Zde jsem člověkem, zde nakupuji.“ Nákupní styl života ochromil demokratickou společnost ztrácející tak svou jasnou identitu. Bauman (2002: 144) uvádí: „Mobilita a flexibilita identifikace, charakterizující nákupní styl života, nejsou ani tak nástroji emancipace, jako spíše nástroji nového přerozdělení svobod.“ Michaud (in Bauman 1997) dodává: „S přemírou možnosti narůstá hrozba destrukce, fragmentace a rozkladu.“ Člověk ztratil sebe sama jako člověka a našel se jako spotřebitel, tj. ten, který musí spotřebovávat, a pouze ve spotřebě a v uspokojení touhy po spotřebě chce člověk nalézt štěstí. Tradiční společnost nabízela jednotlivci identitu $\mathrm{v}$ rámci rádu, $\mathrm{v}$ rámci komunity a také svým sociálním statusem. Oproti tomu moderní masová společnost tuto jistotu člověku nenabízí, člověk musí hledat své místo ve společnosti, které budou ostatní členové společnosti vnímat a respektovat (Müller 2008: 130). Člověk je součástí masy, anonymního kolektivu, snad bychom mohli říci, že člověk je pouze součástí masy spotřebitelů, kteří zakládají blahobyt společnosti.

Ústavní soud v nálezu ze dne 6. 11. 2007, sp. zn. II. ÚS 3/06, uvádí:

Ten, kdo vyvolal určité jednání, se nesmí ex post dovolávat vad jednotlivých úkonů, které sám způsobil. Uplatňování principu důvěry $\mathrm{v}$ úkony dalších osob při veškerém sociálním styku s nimi je základním předpokladem pro fungování komplexní společnosti (Luhmann 1989). Důvěru je třeba pokládat za elementární kategorii sociálního života. Jednak vyjadřuje vnitřní postoj odrážející eticky odůvodněné představy a očekávání jednotlivých členů společnosti a z druhé strany je výrazem principu právní jistoty, který představuje jednu z fazet materiálně, tj. hodnotově, chápaného právního státu, jehož ústavně normativní výraz je obsažen v čl. 1 odst. 1 Ústavy ČR. Naznačená konkretizace principu právního státu je oním principem, který působí na straně stěžovatele a proti principu autonomie vůle, kterého se dovolávají obecné soudy. Je pak primárně úkolem obecných soudů najít praktickou konkordanci mezi oběma protikladně působícími principy tak, aby zůstalo zachováno maximum z obou, a tak, aby výsledek byl slučitelný s obecnou představou spravedlnosti.

Právo jakožto normativní systém, který stanovuje, co býti má, jednoznačně dovozuje, že člověk musí být chráněn ve svém lidství, tj. musí být chráněn jakožto člověk se svou důvěrou v lidství a demokratické principy. Proto i spotřebitel, především jako člověk, musí být chráněn a vnímán nikoli jako součást anonymní masy, ale jako individualizovaná osoba, která vyžaduje ochrany právě pro svou „ztrátu sebe sama“ ve složitosti masové společnosti.

Jestliže kodexy soukromého práva byly v 19. století charakteristické chráněním hodnot svobody a rovnosti, můžeme říci totéž i o civilních kodexech 21. století. Avšak význam chráněné hodnoty svobody a rovnosti subjektů soukromého práva se v průběhu času posunul. Zatímco OZO spočíval na tezi rovnosti před zákonem, tj. měla být zaručena rovnost bez ohledu na postavení subjektu ve společnosti (šlechtic, duchovní, „prostý občan“), tj. šlo především o zakotvení základních lidských práv, civilní kodexy 21. století v zásadě obsahují již presumpci respektování tohoto pravidla (a proto přesun těchto práv do ústavou chráněných práv) a soukromoprávní hodnotu rovnosti posouvají od rovnosti formální (zjednodušeně 
řečeno rovnosti před zákonem) do rovnosti faktické, tj. snaží se nabídnout takové modelové řešení, které ve výsledku povede k tomu, že slabší (nejen spotřebitel) bude chráněn před silnějším, tj. nejen, že si slabý a silný bude roven před zákonem, ale že mezi nimi bude nastolen rovnovážný vztah. Ostatně tendence k ochraně slabších stran v právu jsou známy již od počátku 20. století (např. ochrana zaměstnance).

Zásadní funkci však ochrana slabší strany v soukromém právu dostala s rozvojem blahobytu a „zesložitěním“ naší společnosti (cca od 60. let minulého století). Vznikem masové společnosti a vykořeněním člověka $z$ řádu a komunity člověk znejistěl a hledá sebe sama ve společnosti i v řádu bytí. Člověk-občan se stal spotřebitelem, který sám sebe vnímá někdy jako pouhé „kolečko v soukolí“ mašinerie zvané blahobyt či prosperita společnosti měřené různými ekonomickými metodami (HDP apod.). Nebudeme-li spotřebovávat a nakupovat, zastaví se ona spirála blahobytu a prosperity a celý systém se zhroutí jako dům postavený $\mathrm{z}$ karet. Celý blahobyt naší společnosti je založen na tezi spotřeby jako na základním uhelném kamenu. Není nutné vyrábět „bytelné výrobky jako za našich babiček“, ale je nutné vyrábět a vyrábět, nebot' výrobou se živí občan-spotřebitel. Jde o jakýsi nový způsob „otroctvi““ či začarovaný kruh založený na ideologii spotřeby, př́íp. na ekonomické ideologii.

Právo ovšem jako normativní systém nemůže být pouhým výplodem technologie moci, alespoň demokratická společnost takový př́istup zcela odmítá, a kromě toho, že by mělo reflektovat společenskou realitu, by mělo především stanovovat, co býti má, ovšem vždy $\mathrm{s}$ ohledem na základní hodnoty, jako jsou slušnost, férovost, spravedlnost a v soukromém právu zejména vyváženost vzájemných práv a povinností subjektů právního vztahu.

Civilní kodexy 21. století by měly, a zpravidla tak i činí, reflektovat „spotřebitelský charakter současné společnosti““. Od 60 . let minulého století se v soukromém právu začíná prosazovat ochrana slabší strany - spotřebitele -, protože spotřebitel (člověk) se ocitl ve zcela nerovnovážném vztahu vůči podnikateli, profesionálu, který má velkou výhodu na své straně (znalost věci, četnost uzavírání kontraktů, profesionální právní zázemí atd.) a mnohdy se jí snaží v touze po zisku zneužít. Nebyl-li by spotřebitel chráněn jako slabší strana, pravděpodobně by ještě více rostl ekonomický blahobyt společnosti měřený ekonomickými ukazateli, avšak tento blahobyt by byl založen na nemravném chování podnikatele a parazitování na spotřebiteli (člověku), což demokratická společnost nemůže připustit. Zajímavou skutečností je, že od počátku 21. století můžeme zaznamenat tendence k rozšíření ochrany slabších stran v soukromém právu, tj. opět zásahu do autonomie vůle ve snaze zaručit faktickou rovnost pro jiné subjekty soukromého práva (např. ochrana tzv. drobného podnikatele vůči nadnárodní korporaci, ochrana zemědělského producenta vůči obchodnímu řetězci atd.).

Kodexy soukromého práva jak v 19. století, tak i ve století 21 . mají stále stejnou funkci chránit občana (člověka) a stanovovat jasná pravidla chování pro bezproblémový chod běžného života každého z nás. Věřme, že i kodexy 21. století naplní svůj účel a zaručí občanům svobodu, rovnost a všeobecnou slušnost chování subjektů soukromého práva.

\section{Literatura}

Bar, Christian von et al. 2009. Principles, Definitions and Model Rules of European Private Law. Draft Common Frame of Reference (DCFR). Munich: Sellier European Law Publishers. 
Bauman, Zygmunt. 2002. Tekutá modernita. Praha: Mladá fronta.

Bejček, Josef. 2004. „Princip rovnosti a ochrana slabšího.“ Právní fórum: český právnický měsičník 4: 129-132.

Bejček, Josef. 2013. „Fikce rovnosti, nebo politicky nekorektní realita nerovnosti?“ Právní rozhledy 19: $670-674$.

Brunner, Christoph. 2009. Force Majeure and Hardship under General Contract Principles: Exemption for Non-Performance in International Arbitration. Alphen aan den Rijn: Kluwer Law International.

Cartwright, Peter et al. 1999. Consumer Protection in Financial Services. The Hague: Kluwer Law International.

Eliáš, Karel. 2009. „Clausula rebus sic stantibus. Význam změny okolností pro trvání obligace ex contractu." Obchodněprávní revue 1 (6): 151-155.

Fiala, Josef et al. 2012. MERITUM Občanské právo. Praha: Wolters Kluwer.

Girsberger, Daniel a Paulius Zapolskis. 2012. „Fundamental Alteration of the Contractual Equilibrium under Hardship Exemption.“ Jurisprudencija 19 (1): 125-129.

Horák, Ondřej. 2013. „Dějiny kodifikace soukromého práva v českých zemích.“ Pp. XXVIII-LVII in F. Melzer, P. Tégl et al. Občanský zákoník - velký komentářr. Svazek I. § 1-117. Praha: Leges.

Krajewski, Markus. 2003. „The New German Law of Obligations. “European Business Law Review 14 (2): 201-215.

Lavický, Petr. 2014. „Komentář § 3.“Pp. 51-65 in P. Lavický et al. Občanský zákoník I. Obecná část (§ 1-654). Komentár̆. Praha: C. H. Beck.

Luhmann, Niklas. 1989. Vetrauen. Ein Mechanismus der Reduktion sozialer Komplexität. Stuttgart: Ferdinand Enke Verlag.

Melzer, Filip a Petr Tégl. 2013. „Komentář § 3.“Pp. 78-89 in F. Melzer, P. Tégl et al. Občanský zákoníkvelký komentářr. Svazek I. § 1-117. Praha: Leges.

Müller, Karel B. 2008. Politická sociologie. Politika a identita v proměnách modernity. Praha: Portál.

Ondřej, Jan. 2013. Spotřebitelské smlouvy a ochrana spotřebitele. Ekonomické, právní a sociální aspekty. Praha: C. H. Beck.

Ottova encyklopedie obecných vědomost $i^{\circledR}$. Cit. 22. června 2006 (http://encyklopedie.seznam.cz/heslo/ 436384-spotrebitelska-politika).

Pelikánová, Irena a Robert Pelikán. 2014. „Úvod.“ Pp. XXXIII-LXV in J. Švestka, J. Dvořák, J. Fiala et al. Občanský zákoník. Komentář. Svazek I (\$ 1 až 654). Praha: Wolters Kluwer.

Schulte-Nölke, Hans, Christian Twigg-Flesner a Martin Ebers. 2007. EC Consumer Law CompendiumComparative Analysis. (http://www.eu-consumer-law.org/study_en.cfm).

Selucká, Markéta. 2004. Ochrana slabši strany vztahu jako princip soukromého práva. Diplomová práce. Brno: Masarykova univerzita, Právnická fakulta, Katedra občanského práva.

Selucká, Markéta. 2008. Ochrana spotřebitele v soukromém právu. Praha: C. H. Beck.

Selucká, Markéta. 2009. „Ochrana spotřebitele v navrhovaném občanském zákoníku.“ Právní rozhledy: časopis pro všechna právni odvětví 10: 364-368.

Selucká, Markéta et al. 2013. „Obecné zásady.“Pp. 1-4 in M. Selucká et al. Koupě a prodej. Nový občanský zákoník. Společná evropská právní úprava prodeje. Praha: C. H. Beck.

\section{Autorka}

Markéta Selucká se v roce 2014 habilitovala na Právnické fakultě Masarykovy univerzity s prací „Odpovědnost za vady s důrazem na ochranu spotřebitele“. Nejprve pracovala ve státní správě, později v advokacii a podnikatelské sféře. Je členkou Acquis Group (European Research Group on Existing EC Private Law). Jako národní zpravodaj se účastnila 
projektu Evropské komise „EC Consumer Law Compendium“ řešeného na European Legal Studies Institute (Osnabrück, Německo), projektu Evropské komise „Fundamental Rights Action Plan“ ̌rešeného na European Legal Studies Institute (Osnabrück, Německo) a projektu Evropské komise „The Perspectives of Europeization of Law of Succession“ (v rámci "Civil Justice Programme of the European Commission") řešeného na Akademii Leona Koźmińskiego ve Varšavě (Polsko), Vilniaus universitetas (Litva) a Biznesa Augstskola Turība (Lotyšsko). Zaměřuje se zejména na problematiku ochrany slabších kontraktačních stran v soukromoprávních vztazích, např. ochranu nájemce bytu či spotřebitele.

Kontakt: marketa.selucka@law.muni.cz 